\title{
Abundance, habitat use and diet of Callicebus nigrifrons Spix (Primates, Pitheciidae) in Cantareira State Park, São Paulo, Brazil
}

\author{
Leonardo C. Trevelin '; Marcio Port-Carvalho ${ }^{2}$; Maurício Silveira ${ }^{3}$ \& Eduardo Morell 4
}

\author{
${ }^{1}$ Departamento de Zoologia, Universidade Estadual Paulista. Avenida 24 A 1515, 13506-900 Rio Claro, São Paulo, Brasil. \\ E-mail: leotrevelin@hotmail.com \\ 2 Seção de Animais Silvestres, Instituto Florestal. Rua do Horto 931, 02377-000 São Paulo, São Paulo, Brasil. \\ E-mail: portcar@gmail.com \\ ${ }^{3}$ Rua 1, 2124, Centro, 13506-000 Rio Claro, São Paulo, Brasil. E-mail: maursilv@yahoo.com.br \\ ${ }^{4}$ Rua José dos Santos Castro 92,02375-010 São Paulo, São Paulo, Brasil. E-mail: dumorell@uol.com.br
}

\begin{abstract}
Between april 2005 and May 2006, according to the pressuposts of line transect methodology, census were carried to estimate abundance and population density of Callicebus nigrifrons Spix, 1823 (Pitheciidae) in Cantareira State Park, State of São Paulo, southeastern Brazil (2323'42"S, 46 35'27"W). After 275.80 Km of census sampling effort, the titis were the second most abundant primate species, presenting an abundance index of 1.4 groups for each $10 \mathrm{~km}$ walked and a density estimate of $12.21 \mathrm{ind} . / \mathrm{km}^{2}$ (ranging between 8.45 a 17.63 ind./ $\mathrm{km}^{2}$ ). The collection of ancillary data during the census allowed the determination of diet and habitat use by the titis groups, and results show a relative adaptability to disturbed habitats.
\end{abstract}

KEYWORDS. Atlantic forest; black-fronted titi monkey; conservation; density.

\begin{abstract}
RESUMO. Abundância, uso do habitat e dieta de Callicebus nigrifrons É. Geoffroy (Primates, Pitheciidae) no Parque Estadual da Cantareira, São Paulo, Brasil. Entre abril de 2005 e maio de 2006, através de censos seguindo os pressupostos da metodologia de transecção linear, foram estimadas a densidade populacional e abundância de Callicebus nigrifrons Spix, 1823 (Pitheciidae) no Parque Estadual da Cantareira, Estado de São Paulo,

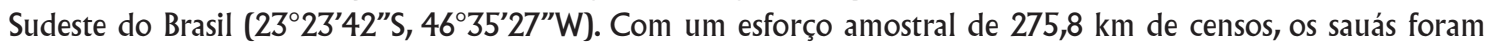
a segunda espécie de primata mais abundante, apresentando um índice de abundância de 1,4 grupos para cada $10 \mathrm{~km}$ percorridos e uma estimativa de densidade de $12,21 \mathrm{ind} . / \mathrm{km}^{2}$ (variando de 8,45 a $17,63 \mathrm{ind} . / \mathrm{km}^{2}$ ). A coleta de dados auxiliares durante os censos possibilitou a verificação da dieta e uso do hábitat pelos grupos de Callicebus, e os resultados evidenciaram uma relativa adaptabilidade à ambientes perturbados.

PALAVRAS-CHAVE. Conservação; densidade; sauás; Mata atlântica.
\end{abstract}

Titi monkeys, genus Callicebus (Thomas, 1903), are a diverse group of neotropical primates found in the Amazon and Orinoco basins, the Brazilian Atlantic Forest, and the Chaco forests of Paraguay and Bolivia (van Roosmalen et al. 2002, Norconk 2007). Callicebus nigrifrons (Spix, 1823) (Pitheciidae) occurs in the Brazilian states of Rio de Janeiro, São Paulo, and Minas Gerais. It occurs on both banks of the upper São Francisco river, ranging eastwards as far as the distribution of Callicebus personatus (É. Geoffroy, 1812) (Pitheciidae) (VAN Roosmalen et al. 2002).

This range coincides with the most densely populated part of Brazil, which has a long history of colonization and deforestation (DEAN 1995). Present-day populations of $C$. nigrifrons are restricted to forest patches within a highly fragmented landscape, where local extinction is a constant threat (van Roosmalen et al. 2002, São Bernardo \& Galetti 2004). Given this situation, C. nigrifrons has been assigned to the near threatened IUCN category (Rylands et al. 2003).

While there is a growing body on knowledge on the ecology and conservation of most Atlantic Forest primate genera, little is known of most Callicebus species, which include the recently discovered Callicebus coimbrai (Kobayashi \& Langguth, 1999) (Pitheciidae) (Kobayashi \& LANGguth 1999). Available studies have focused on Callicebus personatus (Price \& Piedade 2001a, b) and Callicebus melanochir (Wied-Neuwied, 1820) (Pitheciidae) (Müller 1996), although some data are available on populations of C. nigrifrons (OliveIra et al. 2003, São Bernardo \& GaletTI 2004). This study presents the results of a survey of the $C$. nigrifrons population of the Cantareira State Park in São Paulo, which includes detailed information on habitat use and diet. The park is a relatively large remnant of the original Atlantic Forest, located entirely within São Paulo, the largest city in South America. 


\section{MATERIAL AND METHODS}

\section{Study area}

Situated in the Serra da Cantareira $\left(23^{\circ} 23^{\prime} 42^{\prime \prime} S, 46^{\circ} 35^{\prime}\right.$ $27^{\prime \prime}$ ), between the municipalities of São Paulo, Caieiras, Mairiporã and Guarulhos, the Cantareira State Park (CSP) is a 7,917 ha protected area administrated by the São Paulo state Forestry Institute. Totally encompassed by the urban area of São Paulo, Cantareira is not only the World's largest urban forest, but is also one of the most important remnants of the state's Atlantic Forest, and thus has a considerable potential for the conservation of local biodiversity. The park is divided into four administrative nuclei (Fig. 1), three of which (Pedra Grande, Águas Claras, and Engordador) were surveyed during the present study.

\section{Surveys}

To estimate relative abundance, and population density and size, primates were surveyed in Cantareira State Park using standard line transect methodology (Burnham et al. 1980, BuckLAND et al. 1993), between April 2005 and May 2006. Transects were conducted along 12 trails, four trails located in each one of the nuclei. Transects length varied from $0.8 \mathrm{~km}$ to $6 \mathrm{Km}$, with a total length of $19.05 \mathrm{~km}$. During surveys, special attention was paid to the collection of complementary data on the diet and use of habitat (habitat type and vertical spacing) by $C$. nigrifrons.

Habitat was classified according to the schemes provided by previous studies at the site (BAITELlo et al. 1993), modified according to the aims of the present study, with an emphasis on species composition and sucessional stage (Tab. I). The dominant habitat observed along each 50-m interval of the transects was assigned to one of these categories, providing an estimate of the relative cover of each forest type. Habitat preferences were assessed by comparing observed visitation rates (sightings) with those expected according to the relative availability of different habitat types (corrected by sampling effort), and tested by chi-square $\left(\chi^{2}\right)$, following the studies of Peres (1993), Bobadilla $\&$ Ferrari (2000), and Port-Carvalho \& Ferrari (2004).

Analysis of the use of vertical space was based on 5-m height classes, following Peres (1993) and Bobadilla \& Ferrari (2000). Survey data on the diet of $C$. nigrifrons were complemented by ad libitum observations throughout the study period. Specimens were obtained from plants exploited by the titis for identification by a specialist.

\section{RESULTS}

\section{Abundance}

During the 13 month period, we walked a $98.4 \mathrm{~km}$ on the Águas Claras Nucleus, $98.6 \mathrm{~km}$ on the Pedra Grande Nucleus and $78.8 \mathrm{~km}$ on the Engordador Nucleus, with a total of $275.8 \mathrm{~km}$ sample effort, divided in 237 census sessions. The number of sessions in each trail varied from 15 to 25 , so that the total sample effort in each trail was approximately the same for that nucleus. A total of 203 primate sightings were obtained, from witch 39 belonged to groups of Callicebus nigrifrons, approximately $19 \%$ of all sightings. On the other 164 sightings, we encountered the following primate species (in order of encounters): Alouatta clamitans (Cabrera, 1940) (Atelidae), Cebus nigritus (Goldfuss, 1809) (Cebidae) and Callithrix aurita (É. Geoffroy, 1812) (Callitrichidae). Callicebus nigrifrons was the second most abundant species, presenting an abundance index of 1.4 groups for each $10 \mathrm{~km}$ walked. Table II presents this global abundance index as well as the same index for each nucleus.

The average size of troops found in this study was 2.27 individuals per sighting (range = one to five individuals), a slightly smaller troop size than usually observed for this genus (Pinto et al. 1993, Norconk 2007). Sample size was not large enough for reliable calculations of the Effective Strip Width

Table I. Habitat categories used in the present study.

\begin{tabular}{|c|c|}
\hline Forest category & Description \\
\hline Primary & Continuous canopy with tall trees ( $>20 \mathrm{~m}$ in height) and emergents, low density of lianas, and three well-defined strata \\
\hline Late secondary & Discontinuous canopy (15-20 m tall) with few emergents, medium density of lianas, and two strata \\
\hline Early secondary & Discontinuous canopy ( $<15 \mathrm{~m}$ tall), very high density of lianas, and single stratum with dense vegetation \\
\hline Exotic & Dominated by Eucalyptus spp., Pinus spp. and Cryptomeria spp. plantations, with sparse understorey of native species \\
\hline Araucaria & Dominated by Araucaria angustifolia, with dense understorey of native species \\
\hline
\end{tabular}

Table II. Survey sightings (per $10 \mathrm{~km}$ walked) of the primate species observed in the Cantareira State Park.

\begin{tabular}{lcccrr}
\hline \multicolumn{1}{c}{ Nucleus } & Callicebus nigrifrons & Alouatta clamitans & Callithrix aurita & Cebus nigritus & All primates \\
\hline Águas Claras & $17(1.73)$ & $38(3.86)$ & $6(0.61)$ & $11(1.12)$ & $72(7.32)$ \\
Pedra Grande & $10(1.01)$ & $80(8.11)$ & $3(0.30)$ & $3(0.30)$ & $96(9.74)$ \\
Engordador & $12(1.52)$ & $17(2.16)$ & $5(0.60)$ & $1(0.13)$ & $35(4.44)$ \\
All sites & $39(1.41)$ & $135(4.90)$ & $14(0.51)$ & $15(0.54)$ & $203(7.36)$ \\
\hline
\end{tabular}

Revista Brasileira de Zoologia 24 (4): 1071-1077, dezembro 2007 


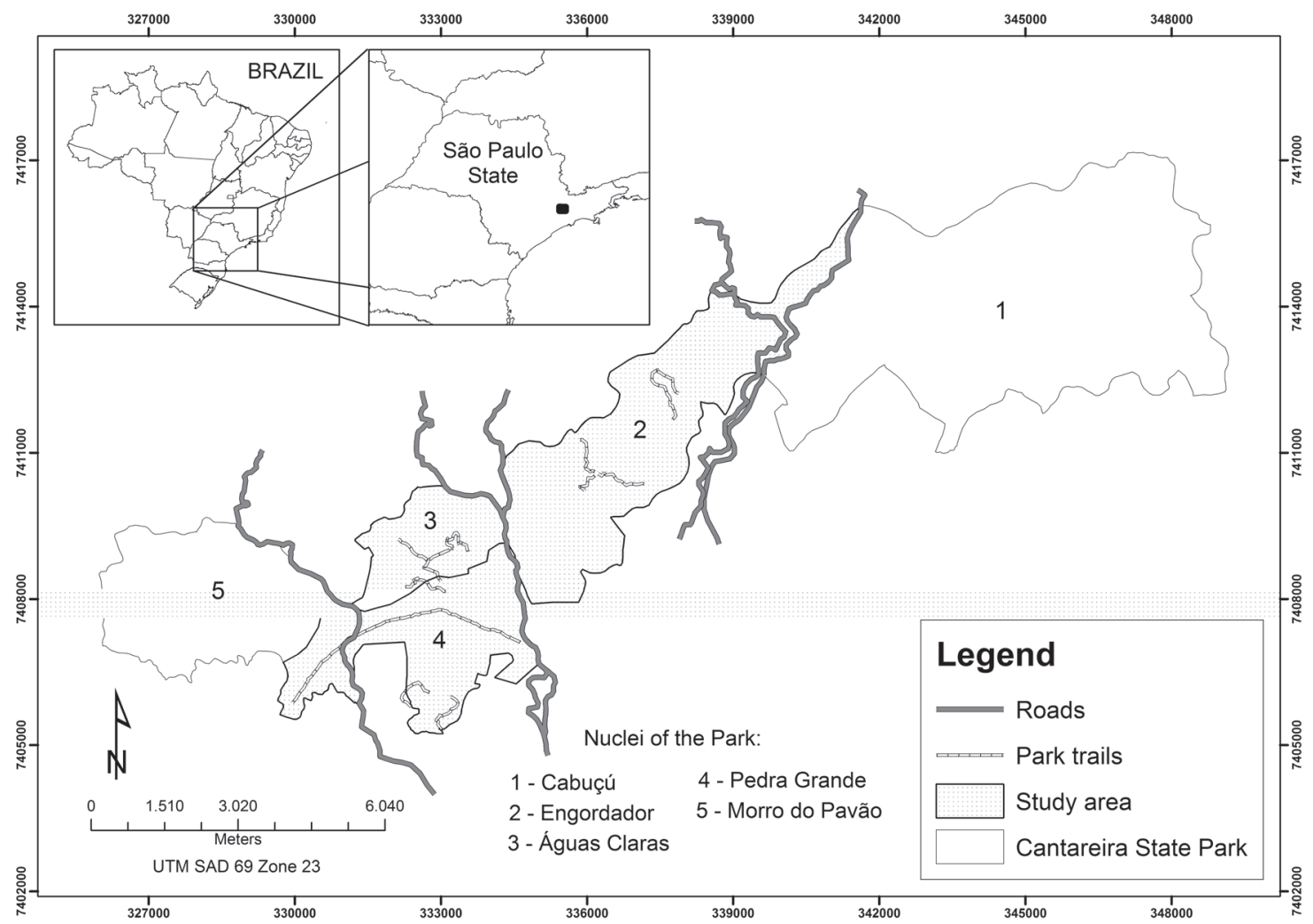

Figure 1. Localization of the Cantareira State Park in the Brazilian state of São Paulo and trails used in the study.

(ESW) and the density parameter in each nucleus separately. Thus the sighting data were pooled and analyzed for the area as a whole. The perpendicular sighting distances were tested for normality (Kolmogorov-Smirnov: 0.1321, p >0.05) and later analyzed with the parametric ANOVA one-way test (F: 0.9085; $p=0.5852$ ). It was possible therefore to generate overall density estimation based on the pooled data for the area as a whole (Chiarello \& Melo 2001), since there was no significant difference between the three nuclei. The uniform key function with the cosine expansion was chosen, witch provided the best fit $(\mathrm{AIC}=184.10$; GOF: $\mathrm{P}=0.84071)$, although other models provided similar estimates of density, witch may be interpreted as data consistency (Tab. III).

\section{Habitat use}

To obtain a reliable statistical analysis, the frequency of each available habitat, as well as the titi's sightings obtained on each nucleus were grouped and analyzed, statistically, in a global way. Since the trails used during the census where of different length and were walked distinctively, the total habitat availability was calculated in function of the effort employed on each trail (Tab. IV).

In the habitat preference analyses, some patterns could be verified, although no significant preference was confirmed for any special habitat $\left(\chi^{2}=4.546, \mathrm{df}=4, \mathrm{p}>0.05\right)$. The Exotic Forest and the Initial Secondary Forest habitats didn't obtain any titi records and the Late Secondary Forest habitat obtained an

Table III. Estimated parameters using program Distance Sampling 4.1 (BuCKLAND et al. 1993).

\begin{tabular}{|c|c|c|c|c|c|}
\hline \multicolumn{2}{|c|}{ Density } & \multicolumn{2}{|l|}{ ESW } & \multirow{2}{*}{ Abundance in sampled area (individuals) } & \multirow{2}{*}{ Population size (individuals) ${ }^{a}$} \\
\hline$\left(\mathrm{km}^{2}\right)$ & CV (\%) & $(\mathrm{m})$ & CV (\%) & & \\
\hline 12,21 & 18.84 & 14.78 & 7.04 & 475 & 967 \\
\hline$(8.45-17,63)$ & & $(12.81-17.05)$ & & $(329-685)$ & $(670-1395)$ \\
\hline
\end{tabular}

a Estimated values obtained trough extrapolation for the whole CSP area (7916.52 ha) from the abundance data in the sampled area (3887 ha). 
Table IV. Proportion of habitats sampled (\%), sample effort $(\mathrm{km})$ and nucleus representativity (\%).

\begin{tabular}{lccccccc}
\hline \multirow{2}{*}{ Localities } & \multicolumn{9}{c}{ Habitats sampled (\%) } & \multirow{2}{*}{ Effort (km) } & Representativity (\%) \\
\cline { 2 - 6 } & Exotic & Araucária & Initial Secondary & Late Secondary & Primary & & \\
& Forest & Forest & Forest & Forest & Forest & & \\
\hline Águas Claras & 6.28 & 61.94 & 0.43 & 25.41 & 5.95 & 98.4 & 35.68 \\
Pedra Grande & 0.00 & 0.00 & 6.34 & 77.99 & 15.67 & 98.6 & 35.75 \\
Engordador & 0.00 & 0.00 & 1.90 & 54.70 & 43.40 & 78.8 & 28.57 \\
\hline Total & 2.24 & 22.10 & 2.96 & 52.57 & 20.12 & 275.8 & 100.00 \\
\hline
\end{tabular}

inferior number than expected, while the Araucaria Forest and the "Primary" Forest obtained more records than it was expected.

The height data on witch the titis were sighted were also pooled and analyzed as a whole, in order to make the analyses more robust. Also, with the same objective, and only for this analyses, the data obtained in opportunistic encounters (ad libitum) during the study where also considered, raising the number of records from 39 to 60 (Fig. 2).

Overall, there was a predominance of sightings in the forest canopy, the " 10 to $14 \mathrm{~m}$ " class or lower canopy, the " 15 to 19 $\mathrm{m}$ " class or intermediate canopy, and from " 20 to $24 \mathrm{~m}$ " class or superior canopy, that together were responsible for $77 \%$ of the Callicebus sightings. We also noticed that the titis came down to the sub-canopy layer frequently (20\% of the records), "05 to 09 $\mathrm{m}$ " class, and also occasionally used the emergent trees over the forest canopy, " 25 to $30 \mathrm{~m}$ " class, with $3 \%$ of the records.

Diet

We observed the titis consume 15 species belonging to nine families. Fruit pulp was the principal item consumed for most the species (Tab. V). We also observed some individuals ingesting arthropods on three occasions, indicating this food item may complete the titis diet.

\section{DISCUSSION}

The density and relative abundance estimates of the present study conform to similar studies carried out with species of the Callicebus genus in Brazilian Atlantic Forest (Tab. VI).

Abundance indexes expressed little difference between nuclei, except for the smaller Pedra Grande, were the total primate abundance was greater. This difference was probably related to the very high abundance of howler monkeys Alouatta clamitans, in contrast with the reduction of abundance indexes for Callithrix aurita, Cebus nigritus and the titis. The Pedra Grande nucleus had the greatest secondary forest availability, and the tourist pressure is often more intense, compared with the other nuclei. Despite this difference, the titis were the second most abundant primate species in all nuclei in CSP, and presented an overall density estimate larger than most of the studies presented

\begin{tabular}{llll}
\hline \multicolumn{1}{c}{ Table V. Plant species consumed by Callicebus nigrifrons during the study. } & & \\
\hline \multicolumn{1}{c}{ Family } & \multicolumn{1}{c}{ Species } & Habitus & Item consumed \\
\hline Bignoniaceae & Pithecoctenium sp. & Tree & Imature seed * \\
Euphorbiaceae & Alchornea triplinervia & Tree & Fruit \\
& Tetrorchidium rubrivenium & Free & Seed \\
Fabaceae & Croton floribundus & Tree & Fruit and flower \\
& Inga marsilis & Tree & Fruit \\
Lauraceae & Persea americana & Tree & Fruit \\
Melastomataceae & Miconia cinnamomifolia & Tree & Leaf \\
Myrtaceae & Eugenia involucrata & Tree & Fruit \\
& Myrciaria sp. & Tree & Fruit \\
& Psidium guajava & Tree & Fruit \\
Rosaceae & Prunnus sellowiana & Tree & Leaf \\
Sapindaceae & Cupania oblongifolia & Tree & Fruit \\
& Paullinia sp. & Tree & Fruit \\
Solanaceae & Solanum mauritianum & Liana & Fruit, flower, imature leaf and branch \\
\hline
\end{tabular}

* The collected material contained a Coleopteran larva, making it impossible to define precisely the consumed item. 


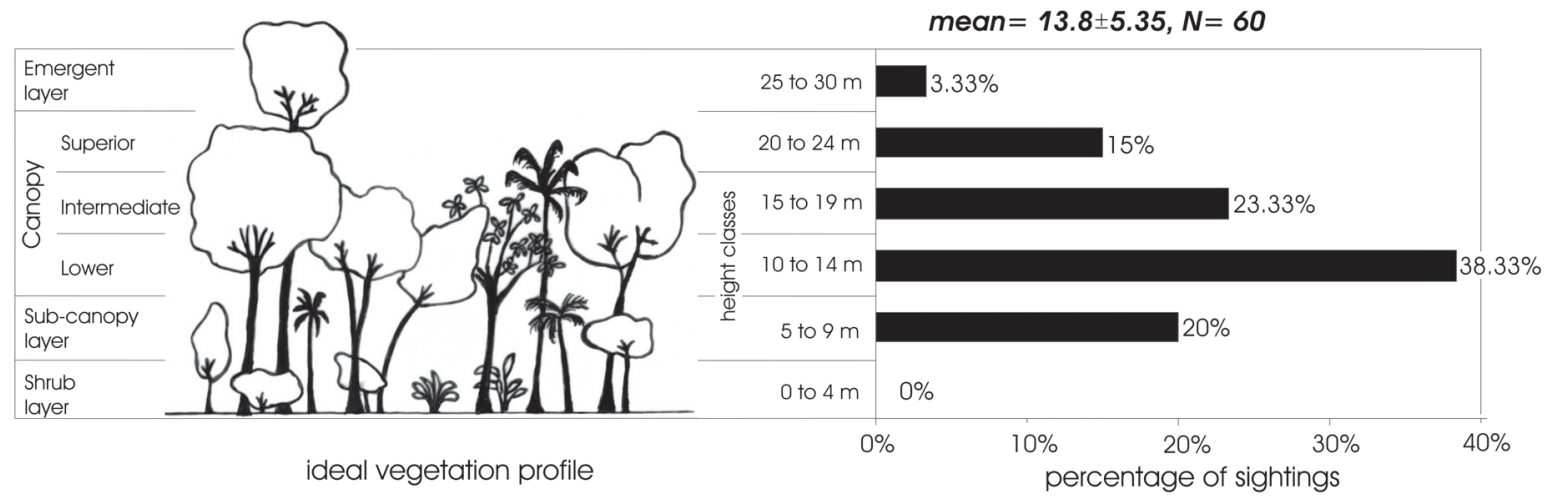

Figure 2. Ideal vegetation profile in Cantareira State Park with the vertical layer usage frequency by Callicebus nigrifrons.

in table VI, although they had a slightly lower troop size $(2.27$ individuals) than observed in most studies (PINTO et al. 1993, NorConk 2007). Some of this variation can be explained by sample differences and systematic errors that may arrise whith violations of the basic assumptions of line transect census theory, but can we hypothesize this as adaptations to perturbation? Chiarello (2003), comparing primate census data for São Paulo and Espírito Santo, could not find any correlation between fragment size and density/abundance parameters for most primates, except for Brachyteles hypoxanthus (Kuhl, 1820) (Atelidae), indicating a certain ecological flexibility of the Brazilian Atlantic Forest primates, witch demonstrates a rather extensive adaptative capacity to perturbation caused by fragmentation.

Some studies relate the occurrence and persistence of titis in secondary forests fragments from several sizes of Brazilian Atlantic forests (Stallings \& Robinson 1991, Pinto et al. 1993, Heiduck
2002, São Bernardo \& Galetti 2004, Martins 2005). However, Heiduck (2002) showed that despite utilizing both secondary and primary forests, the home ranges of troops always contained a major portion of primary forest, and that habitat use was much more related to food resource availability than the proportional availability of each habitat. In the CSP, C. nigrifrons did not show any statistically significant preference for any kind of habitat, occurring in all habitats, except for initial secondary and exotic forests.

With regard to the vertical stratification observed, the titis exhibited a considerable preference for the lower canopy (10 to 14 meters class). This corroborates with the overall pattern relating the height of strata used to body size and locomotion mode for primates (CunHA et al. 2006). Callicebus is a medium sized primate occurring in all strata, but showing a preference for intermediate strata (RYLANDs et al. 1996, CunHa et al. 2006).

Table VI. Density and relative abundance estimates of Callicebus on different localities of Brazilian Atlantic Forest.

\begin{tabular}{|c|c|c|c|c|c|}
\hline Species & Study area & $\begin{array}{l}\text { Fragment } \\
\text { area }\left(\mathrm{km}^{2}\right)\end{array}$ & $\begin{array}{l}\text { Density } \\
\text { (ind } / \mathrm{km}^{2} \text { ) }\end{array}$ & $\begin{array}{c}\text { Sighting rate } \\
\text { (groups } / 10 \mathrm{~km} \text { ) }\end{array}$ & Reference \\
\hline \multirow[t]{5}{*}{ C. nigrifrons } & Cantareira State Park, São Paulo & 79.2 & 11.21 & 1.43 & Present study \\
\hline & Barreiro Rico, São Paulo & 32.6 & $7.0-10.0$ & - & PINTO et al. (1993) \\
\hline & São José, São Paulo & 2.3 & 3.5 & 0.56 & São Bernardo \& GaletTI (2004) \\
\hline & Serra do Brigadeiro, Minas Gerais & 132.1 & 10.3 & - & Cosenza \& Melo (1998) \\
\hline & Viçosa, Minas Gerais & 0.8 & 14.86 & 1.83 & OLIVEIRA et al. (2003) \\
\hline \multirow[t]{6}{*}{ C. personatus } & Augusto Ruschi Biological Reserve, Espírito Santo & 40.0 & 5.4 & 0.54 & PINTO et al. (1993) \\
\hline & Linhares Forest Reserve, Espírito Santo & 218.0 & 7.7 & 1.23 & Chiarello \& Melo (2001) \\
\hline & Linhares Forest Reserve, Espírito Santo & 218.0 & $12.3-12.6$ & - & PrICE et al. (2002) \\
\hline & $M 7 / 317$, Espírito Santo & 2.6 & 1.4 & 0.22 & Chiarello \& Melo (2001) \\
\hline & Putiri, Espírito Santo & 2.1 & 6.4 & 1.02 & Chiarello \& Melo (2001) \\
\hline & Sooretama Biological Reserve, Espírito Santo & 242.5 & 9.5 & 1.66 & Chiarello \& Melo (2001) \\
\hline \multirow[t]{3}{*}{ C. melanochir } & CEPLAC, Bahia & 10.0 & 17.0 & - & MÜLLER (1996) \\
\hline & Teimoso Farm, Bahia & 2.4 & 17.7 & - & PINTO et al. (1993) \\
\hline & Una, Bahia & 1.0 & $3.4-16.7$ & - & PINTO et al. (1993) \\
\hline
\end{tabular}


Observations of plant species consumed by C. nigrifrons are consistent with the literature, especially with the basically frugivorous pattern of diet (NorCONK 2007). However, the actual components of this diet are subject to debate, since various species of the Callicebus personatus group, especially C. nigrifrons show much variation in specific diet. KINZEY \& BECKER (1983) studying C. personatus, Müller (1996) studying C. melanochir and Price \& Piedade (2001a) also studying the C. personatus species found the complement of diet to consist entirely of leaves, while HeIDuck (1997) working with C. melanochir relate a diet complemented with insects in addition to leaves, witch matches the observation of this feeding behavior in the CSP. Other interesting aspect was the major presence of typically secondary species in the titis diet, especially the tapiá (Alchornea triplinervia) and the ingás (Inga sessilis e I. marginata), which were frequently recorded during their fruiting season. Could these records again be evidence of the high adaptability of this species to secondary forest areas? This feeding flexibility and consequent adaptability to variations in resource availability, in terms of component diversity and feeding behavior, could explain not only these regional differences in diet but also the apparent persistence success in altered and fragmented forest areas. More specifically designed studies of diet aiming to solve these ecological questions for titis are of fundamental importance not only to the better understanding of this species, but also to its adequate management in protected areas.

The population size estimated for CSP by this study was approximately 967 individuals (Tab. III). If we choose to consider the average group size of 2.2 individuals obtained by linear transects to be lower than the literature data (NorConk 2007), this estimate may be thought as an underestimate of the true situation. Even so, values somewhat higher than 967 individuals are still smaller than the minimal viable population size of 7,000 individuals, as suggested by REED et al. (2003) to avoid long-term genetics, demographics and stochastic effects. On the other hand, BRITO \& GRELLE (2006) working with stochastic population models for Brachyteles hypoxanthus, an Atlantic forest endemic primate species, estimated that a minimum viable population of 700 individuals could guarantee the long-term survival of this taxon. From this standpoint, if we assume that the estimated value for the the viability of the northern-muriqui population, a larger body sized species than C. nigrifrons, are also enough for smaller body size species, our estimates of titi monkey populations in CSP overcome the necessary for their long term survival.

A major concern, however, is that the situation in CSP is aggravated by the fact that the Park is strip-cut by roads that probably reduce mixing between, if not isolate (in the Fernão Dias Highway case, see figure 1), sub-populations of the whole C. nigrifrons park population. Roads alter animal behavior by causing changes in home ranges, movement, reproductive success, escape response, and physiological state, and studies show that the presence of roads is highly correlated with changes in species composition and population sizes (TrombulaK \& Frissell
2000), pointing this as a possible immediate threat to their long-term conservation.

This and other problems for the conservation not only of the titis, but of all other primate species that occur in the CSP are closely related to its proximity to the biggest urban center of Latin America. To guarantee the long term conservation of these primates in the metropolitan region of São Paulo city, legal and political measures and concrete actions must be orchestrated in conformity with a pre-defined strategy that supports the conservation of this and other taxa (Chiarello 2003).

This study showed that the Callicebus nigrifrons population in CSP, a medium sized primate species with intermediate abundance in the primate community, is comparatively well established in this 7,917 ha forest reserve. They present almost no habitat limitation on occurrence, responding well to secondary forest, a predominant habitat in the CSP. The population size we estimated could guarantee its short-term survival, but in the long-term, roads and the urbanization of the park's surroundings may represent a considerable threat for its conservation.

\section{ACKNOWLEDGMENTS}

To Stephen F. Ferrari and two anonymous reviewers for the review and valuable comments, to Philipp Withers and Cristine Cooper for the help with the English version, to all the personnel in CSP and Forestry Institute of São Paulo for permitting the realization of this work (SMA Process 42.052/ 2005), to the Botanist Geraldo Daher Côrrea Franco (Forestry Institute of São Paulo) for the identifications of the botanical specimens, Tessio Novack (INPE) and Cristiano Figueira (FFLCHUSP) for helping with the nuclei areas and the localization map.

\section{REFERENCES}

Baitello, J.B.; O.T. Aguiar; F.T. Rocha; J.A Pastore \& R. Esteves. 1993. Estrutura fitossociológica da vegetação arbórea da Serra da Cantareira (SP) - Núcleo Pinheirinho. Revista do Instituto Florestal 5 (2): 103-191.

Bobadilla, U.L. \& S.F. Ferrari. 2000. Habitat use by Chiropotes satanas utahicki and syntopic platyrrhines in eastern Amazonia. American Journal of Primatolology 50: 215-224.

Brito, D. \& C.V. Grelle. 2006. Estimating minimum area of suitable habitat and viable population size for the northern muriqui (Brachyteles hypoxanthus). Biodiversity and Conservation 15: 4197-4210.

Buckland, S.T.; D.R. Anderson; K.P. Burnham \& J.L. LaAke. 1993. Distance sampling: estimating abundance of biological populations. London, Chapman and Hall, 432p.

Burnham, K.P.; D.R. Anderson \& J.L. LaAKe. 1980. Estimation of density from line transect sampling of biological populations. Wildlife Monographs 72: 1-202.

Chiarello, A.G. 2003. Primates of the Brazilian Atlantic Forest: the influence of forest fragmentation on survival, p. 99-118. In: L.K. MARSH (Ed.). Primates in fragments: ecology and 
conservation. New York, Kluwer Academic, Plenum Publishers, 428p.

Chiarello, A.G. \& F.R. Melo. 2001. Primate population densities and sizes in Atlantic Forest remnants of Northern Espirito Santo, Brazil. Internacional Journal of Primatology 22 (3): 379-396.

Cosenza, B.A.P. \& F.R. Melo. 1998. Primates of the State Park, Minas Gerais, Brazil. Neotropical Primates 6 (1): 18-20.

Cunha, A.A.; M.V. Vieira \& C.E.V. Grelle. 2006. Preliminary observations on habitat, support use and diet in two nonnative primates in an urban Atlantic forest fragment: The capuchin monkey (Cebus sp.) and the common marmoset (Callithrix jacchus) in the Tijuca forest, Rio de Janeiro. Urban Ecosystem 9 (4): 351-359.

DEAN, W. 1995. With broadax and firebrand: the destruction of the Brazilian Atlantic Forest. Berkeley, University of California Press, 504p.

Heiduck, S. 1997. Food Choice in Masked Titi Monkeys (Callicebus personatus melanochir): Selectivity or Opportunism? Interntional Journal of Primatology 18 (4): 487-502.

Heiduck, S. 2002. The use of disturbed and undisturbed forest by masked titi monkeys Callicebus personatus melanochir is proportional to food availability. Oryx 36: 133-139.

KinZeY, W.G. \& M. BeCKer 1983. Activity Pattern of the Masked Titi Monkey, Callicebus personatus. Primates 24 (3): 337-343.

Kobayashi, S. \& A. Langguth. 1999. A new species of titi monkey, Callicebus Thomas, from north-eastern Brazil (Primates, Cebidae). Revista Brasileira de Zoologia 16 (2): 531-551.

Martins, M.M. 2005. Density of primates in four semi-deciduous forest fragments of São Paulo, Brazil. Biodiversity and Conservation 14: 2321-2329.

MülLER, K.H. 1996. Diet and feeding ecology of Masked Titis (Callicebus personatus), p. 383-401. In: M.A. NorConk; A.L. Rosenberger, \& P.A. Garber (Eds). Adaptative radiations of Neotropical Primates. Illinois, Plenum Press, 490p.

Norconk, M.A. 2007. Sakis, uakaris, and titi monkeys, p. 123138. In: C.J. Campbell; A. Fuentes; K. MacKinnon; M. Panger \& S.K. Bearder (Eds). Primates in perspective. New York, Oxford University Press, 720p.

Oliveira, R.C.R.; A.S. Coelho \& F.R. Melo. 2003. Estimativa de densidade e tamanho populacional de sauá (Callicebus nigrifrons) em um fragmento de mata em Regeneração, Viçosa, Minas Gerais, Brasil. Neotropical Primates 11 (2): 91-93.

Peres, C.A. 1993. Structural and spatial organization of an Amazoniam terra firme forest primate community. Journal of Tropical Ecology 9: 259-276.
Pinto, L.P.S.; C.M.R. Costa; K.B. Strier \& G.A.B Fonseca. 1993. Habitat, density and group size of primates in a Brazilian tropical forest. Folia Primatologica 61: 135-143.

Port-Carvalho, M. \& S.F. Ferrari. 2004. Occurrence and diet of the black bearded saki (Chiropotes satanas satanas) in the fragmented landscape of western Maranhão, Brazil. Neotropical Primates 12 (1): 17-21.

Price, E.C. \& H.M. Piedade. 2001a. Diet of Northern Masked Titi Monkeys (Callicebus personatus). Folia Primatologica 72: 335-338.

Price, E.C. \& H.M. Piedade. 2001b. Ranging behaviour and intraspecific relationships of masked titi monkeys Callicebus personatus personatus. American Journal of Primatology 53: 8792.

Price, E.C.; H.M. Piedade \& D. Wormell. 2002. Population densities of primates in a Brazilian Atlantic forest. Folia Primatologica 73 (1): 54-56.

Reed, D.H.; J.J. O’Grady; B.W. Brook; J.D. Ballou \& R. Frankham. 2003. Estimates of minimum viable population sizes for vertebrates and factors influencing those estimates. Biological Conservation 113: 23-34.

Rylands, A.B.; G.A.B. Fonseca; Y.R. Leite \& R.A. Mittermeier. 1996. Primates of the Atlantic forest: origin, distribution, endemism and communities, p. 21-49. In: M.A. NORCONK; A.L. ROSENBERGER $\&$ P.A. GARBER (Eds). Adaptative radiations of Neotropical Primates. Illinois, Plenum Press, 490p.

Rylands, A.B.; M.I. Bampi; A.G. Chiarello; G.A.B. Da Fonseca; S.L. Mendes \& M. Marcelino. 2003. Callicebus nigrifrons. In: IuCN 2007. 2007 IUCN Red List of Threatened Species. Available at: http://www.iucnredlist.org/search/details.php/39943/ summ [Accessed in 18.X.2007]

São Bernardo, C.S. \& M. Galetti. 2004. Densidade e tamanho populacional de primatas em um fragmento florestal no sudeste do Brasil. Revista Brasileira de Zoologia 21 (4): 827-832.

Stallings, J.R. \& J.G. Robinson. 1991. Disturbance, forest heterogeneity and primate communities in a Brazilian Atlantic Forest Park, p. 357-368. In: A.B. Rylands \& A.T. Bernardes. (Eds). A Primatologia no Brasil. Brasília, SBPr, vol. 3, 420p.

Trombulak, S.C. \& C.A. Frissell. 2000. Review of ecological effects of roads on terrestrial and aquatic communities. Conservation Biology 14 (1): 18-30.

van Roosmalen, M.G.M.; T. van Roosmalen \& R.A. Mittermeier. 2002. Taxonomic review of the Titi monkeys, genus Callicebus Thomas, 1903, with the description of two new species, Callicebus bernhardi and Callicebus stephennashi, from Brazilian Amazonia. Neotropical Primates 10 (Suppl.): 1-52. 